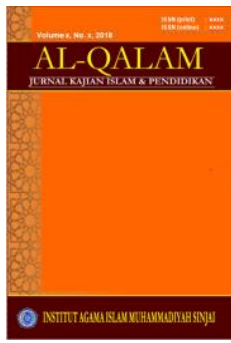

\title{
KONSEP MANAJEMEN PENDIDIKAN ISLAM DALAM PERSFEKTIF AL-QUR'AN
}

\author{
Oleh : Safaruddin ${ }^{1}$ \\ $* * *$
}

\begin{abstract}
Abstrak
Manajemen pendidikan Islam adalah suatu proses penataan dan pengelolaan lembaga pendidikan Islam yang melibatkan sumber daya manusia muslim dan sumber daya manusia dalam rangka menggerakkan lembaga pendidikan Islam untuk mencapai tujuan pendidikan Islam yang telah dirumuskan secara efektif dan efisien. Paradigma pendidikan dalam Al-qur'an tidak lepas dari tujuan Allah SWT menciptakan manusia itu sendiri, yaitu pendidikan penyerahan diri secara ikhlas kepada sang Kholik yang mengarah pada tercapainya kebahagiaan hidup dunia maupun akhirat. Para ahli mengabstraksikan proses manajemen menjadi 4 proses. Yaitu, planning, organizing, actuating, dan controlling (PAOC). Empat proses manajemen ini digambarkan dalam bentuk siklus karena adanya saling keterkaitan antara proses yang pertama dan berikutnya, begitu juga setelah pelaksanaan controlling lazimnya dilanjutkan dengan membuat planning baru hingga siklus proses manajemen akan selalu berputar
\end{abstract}

Kata Kunci : Menejemen, pendidikan Islam dalam Al-qur'an

\section{PENDAHULUAN}

Al-qur'an merupakan inspirator utama dalam mengarahkan dan membina kehidupan umat manusia. Sudah terbukti berabad-abad lamanya ajaran Islam tampil dengan menyumbang dan memimpin ilmu pengetahuan dalam berbagai disiplin ilmu. Tanpa ilmu yang diinspirasikan Al-qur'an, manusia akan buta dan hidup ini gelap gulita sepanjang masa. Sinar ilmu dari Allah SWT telah membawa manusia ke derajat makhluk yang terpilih sehingga mampu menjadi khalifah di muka bumi ini. Cukup banyak temuan ilmiah mutakhir tentang petunjuk Alqur'an di berbagai bidang ilmu pengetahuan, dalam hal ini termasuk pengetahuan tentang konsep-konsep manajemen pendidikan Islam dalam Al-qur'an. Bahkan para pemikir dan ilmuwan barat telah mengakui bahwa Al-qur'an adalah sumber inspirasi pertama dari beberapa cabang ilmu pengetahuan sejak dulu sampai kini.

Al-qur'an adalah petunjuk jalan yang benar bagi setiap kegiatan manusia, apakah itu antara manusia dengan Tuhannya (Hablu minAllah) maupun dengan sesama manusia (Hablu minannas) dan segala hubungan dengan makhluk lainnya. Kitab suci ini menyebutkan, bahwa manusia itu memang sudah fitrahnya atau sudah kudrat Allah yang dijadikan berbangsa, bersuku, berkelompok untuk saling

\footnotetext{
${ }^{1}$ Dosen STAI Muhammadiyah Sinjai
} 


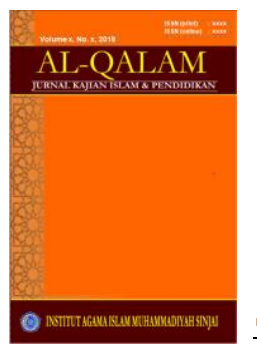

AL-QALAM

Jurnal Kajian Islam \& Pendidikan

Volume 06 No 022014

ISSN (print) : 1858-4152

ISSN (online) : -

Homepage : http://journal.iaimsinjai.ac.id/index.php/al-qalam

berbuat baik sesamanya. Oleh karena itu, pengetahuan manajemen yang mempelajari bagaimana kegiatan kelompok dapat menciptakan suasana yang baik, damai, tertib serta mendapatkan keberhasilan, kemenangan sesuai dengan kebutuhan dan yang telah ditetapkan sebelumnya di dalam perencanaan.

Di dalam bahasa Arab manajemen terambil dari kata nazhama. Nazhama al asyyaa' nazhman berarti menata beberapa hal dan menggabungkan antara satu dengan yang lainnya. Menilik arti manajemen ini sesungguhnya dapat ditegaskan bahwa dalam implementasi amal-amal Islami, Al-qur'an sangat mementingkan dan memperhatikan unsur idariyah (manajemen). Ketaatan pada substansi ajaran, pada pedoman dan panduan pelaksanaan serta pilihan untuk menciptakan titik optimal, merupakan rangkaian manajemen. Dengan demikian dalam beramal Islami, penting untuk diperhatikan adalah fiqhu al ahkam (pemahaman terhadap hukum dan aturan), kaifiyat al tathbiq (tata cara pelaksanaan), dan ikhtiyar al afdhal (memilih yang utama dan optimal).

Ajaran Islam memandang bahwa segala sesuatu harus dilakukan secara rapi, benar, tertib, dan teratur. Proses-prosesnya juga harus diikuti dengan baik. Sesuatu tidak boleh dilakukan secara asal-asalan. Mulai dari urusan terkecil seperti mengatur urusan Rumah Tangga sampai dengan urusan terbesar seperti mengatur urusan sebuah negara dan apalagi urusan mengenai pendidikan, yang mana pendidikan dianggap sebagai upaya pembentukan manusia berkualitas dan seutuhnya (Insan kamil). Sehingga semua itu diperlukan pengaturan yang baik, tepat dan terarah dalam bingkai sebuah manajemen agar tujuan yang hendak dicapai bisa diraih dan bisa selesai secara efisien dan efektif. Untuk itulah dalam tulisan ini penulis mencoba mensinergiskan dan mengungkap secara langsung bahwa konsep manajemen pendidikan Islam sesungguhnya dapat kita kaji dan kita interpretasikan melalui Al-qur'an.

\section{PEMBAHASAN}

\section{Pengertian Manajemen Pendidikan Islam}

Sulistyorini merumuskan pengertian manajemen pendidikan Islam dengan sebuah rumusan bahwa pengertian manajemen pendidikan Islam adalah suatu proses penataan dan pengelolaan lembaga pendidikan Islam yang melibatkan sumber daya manusia Muslim dan sumber daya non manusia dalam rangka menggerakkan lembaga pendidikan Islam untuk mencapai tujuan pendidikan Islam yang telah dirumuskan secara efektif dan efisien. ${ }^{2}$

Dalam pandangan ajaran Islam, segala sesuatu harus dilakukan secara rapi, benar, tertib, dan teratur. Proses-prosesnya harus diikuti dengan baik. Sesuatu tidak boleh dilakukan secara asal-asalan. Hal ini merupakan prinsip utama dalam ajaran Islam yang merupakan perwujudan nilai-nilai manajemen

${ }^{2}$ Sulistyorini, Manajemen Pendidikan Islam; Konsep, Strategi dan Aplikasi, Yogyakarta: Penerbit TERAS, 2009, hal. 14. 


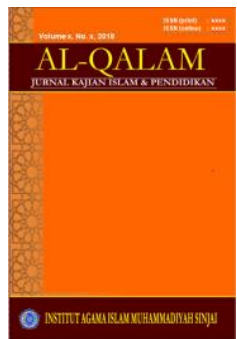

yang terdapat dalam ajaran Islam. Rasulullah saw. bersabda dalam sebuah hadis yang diriwayatkan oleh Imam Thabrani. ${ }^{3}$

$$
\text { إن الله يحب إذا عمل احدكم لعمل أن يتقنه (رو اه الطبر انى) }
$$

"Sesungguhnya Allah sangat mencintai orang yang jika melakukan sesuatu pekerjaan, dilakukan secara itqan (tepat, terarah, jelas, dan tuntas)." (HR. Thabrani)

Arah pekerjaan yang jelas, landasan yang mantap, dan cara-cara mendapatkannya yang transparan merupakan amal perbuatan yang dicintai Allah swt. sebenarnya, manajemen dalam arti mengatur segala sesuatu agar dapat dilakukan dengan baik, tepat, dan tuntas merupakan hal yang disyariatkan dalam ajaran Islam.

Demikian pula dalam hadis yang diriwayatkan oleh Imam Muslim dari Abu Ya'la, Rasulullah saw bersabda: ${ }^{4}$

$$
\text { إن الله كتب الاحسان على كل شئ (رو اه مسلم) }
$$

"Allah swt. mewajibkan kepada kita untuk berlaku ikhsan dalam segala sesuatu.” (HR. Muslim)

Kata ikhsan pada hadis di atas mengandung makna melakukan sesuatu secara maksimal dan optimal. Seorang Muslim tidak boleh melakukan sesuatu tanpa adanya perencanaan, pemikiran, kajian, dan penelitian kecuali pada sesuatu yang bersifat sangat darurat. Akan tetapi, pada umumnya dari permasalahan yang kecil hingga permasalahan yang besar harus dilakukan secara ikhsan, optimal, baik, benar, dan tuntas. ${ }^{5}$ Inilah beberapa nilai dalam ajaran Islam yang memiliki moralitas sama dengan nilai-nilai dalam disiplin ilmu manajemen modern.

Setiap organisasi memiliki aktivitas-aktivitas pekerjaan tertentu dalam rangka mencapai tujuan organisasi, termasuk di dalamnya lembaga-lembaga pendidikan Islam. Salah satu aktivitas yang paling urgen dalam sebuah organisasi adalah manajemen. Manajemen sebagai ilmu yang baru dikenal pada pertengahan abad ke-19, dewasa ini sangat populer, bahkan dianggap sebagai kunci keberhasilan dalam pengelolaan sebuah organisasi. Bahkan tidak jarang para pakar manajemen yang mengatakan bahwa manajemen adalah sebagai ciri khas kemoderenan bagi sebuah organisasi yang termasuk di dalamnya adalah lembega-lembaga pendidikan Islam. ${ }^{6}$

Tidak dapat disangkal lagi bahwa manajemen adalah suatu hal penting yang menyentuh, mempengaruhi, dan bahkan merasuki hampir seluruh aspek

\footnotetext{
${ }^{3}$ Ibid. 1 .

${ }^{4}$ Ibid

${ }^{5}$ Sulistyorini, Manajemen Pendidikan Islam; Konsep, Strategi dan Aplikasi, Yogyakarta: Penerbit TERAS, 2009, hal. 2.

${ }^{6}$ Ibid: 3 .
} 


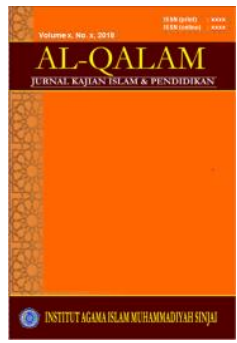

AL-QALAM

Jurnal Kajian Islam \& Pendidikan

Volume 06 No 022014

ISSN (print) : 1858-4152

ISSN (online) : -

Homepage : http://journal.iaimsinjai.ac.id/index.php/al-qalam

kehidupan manusia. Manajemen menunjukkan cara-cara yang lebih efektif dan efisien dalam pelaksanaan suatu pekerjaan. Manajemen memungkinkan untuk mengurangi hambatan-hambatan dalam rangka pencapaian suatu tujuan. Manajemen juga memberikan prediksi dan imajinasi agar dapat melakukan antisipasi perubahan lingkungan yang serba cepat dan tidak menentu. ${ }^{7}$

Manajemen yang tidak efektif, yaitu manajemen yang tidak berhasil memenuhi tujuan karena terjadinya mis-manajemen. Manajemen yang efektif tetapi tidak efisien adalah manajemen yang berhasil mencapai tujuan tetapi melalui pengahamburan atau pemborosan anggaran, tenaga, dan waktu. Sedangkan manajemen yang efisien adalah manajemen yang berhasil mencapai tujuan yang telah dirumuskan dengan sempurna, cepat, tepat, dan selamat. ${ }^{8}$

Dengan demikian, manajemen pendidikan Islam secara umum dapat dipahami sebagai proses untuk mencapai serangkaian cita-cita dan tujuan organisasi atau lembaga pendidikan Islam, melalui aktivitas bersama dengan menggerakkan, memobilisasi, dan mengaktifkan seluruh potensi sumber daya manusia spirituil dan materil (dzikir dan pikir), guna kelangsungan dalam memajukan usaha dan mendapatkan nilai tambah yang berdampak luas. Pencapaian tersebut akan ditengarai oleh adanya keefektifan, efisiensi, inovasi dan pemegang peran yang tangguh serta bertanggungjawab. Hal ini juga mengandung arti seni bekerja sama untuk mencapai tujuan yang telah dirumuskan dan disepakati bersama. ${ }^{9}$

Oleh karena itu, para pelaku dan pengambil kebijakan di lembagalembaga pendidikan Islam harus dapat bertindak untuk dapat menghadapi perubahan-perubahan yang terus berlangsung, harus dapat melakukan langkahlangkah antisipatif dalam menghadapi perubahan yang makin tidak menentu, dan harus selalu berinovasi untuk mewujudkan manajemen pendidikan Islam yang profesional.

\section{Pendidikan Islam dalam Perspektif Al-qur'an}

Paradigma pendidikan dalam Al-qur'an tidak lepas dari tujuan Allah SWT menciptakan manusia itu sendiri, yaitu pendidikan penyerahan diri secara ikhlas kepada sang Kholik yang mengarah pada tercapainya kebahagiaan hidup dunia maupun akhirat, sebagaimana Firman-Nya dalam QS. Adz-Dzariyat: 56 : "Tidak semata-mata kami ciptakan jin dan manusia kecuali hanya untuk beribadah". Bahwa tujuan pendidikan dalam Al-qur'an adalah membina manusia secara pribadi dan kelompok, sehingga mampu menjalankan

\section{${ }^{7}$ Ibid: 7.}

${ }^{8}$ Ibid: 14.

${ }^{9}$ Winarno Surakhmad, dkk, Reformasi Pendidikan Muhammadiyah Suatu Keniscayaan, Yogyakarta: Pustaka Suara Muhammadiyah, 2003, hal. 143. 


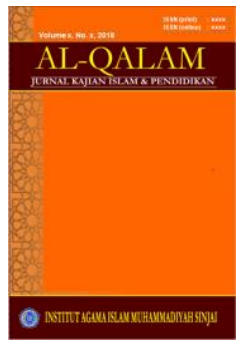

fungsinya sebagai hamba Allah SWT dan kholifah-Nya, guna membangun dunia ini sesuai dengan konsep yang diciptakan Allah". ${ }^{10}$

Pendidikan dalam perspektif Al-qur'an dapat dilihat bagaimana Luqman Al-Hakim memberikan pendidikan yang mendasar kepada putranya, sekaligus memberikan contohnya, juga menunjukkan perbuatannya lewat pengamalan dan sikap mental yang dilakukannya sehari-hari dalam rangka mendekatkan diri kepada Allah SWT. Diantara wasiat pendidikan 'monumental' yang dicontohkan Luqman lewat materi billisan dan dilakukannya lewat bilamal terlebih dahulu adalah: Jangan sekali-kali menyekutukan Allah, berbuat baiklah kepada kedua orang tua, jangan mengikuti seruan syirik, ingatlah bahwa manusia itu pasti mati, hendaklah kita tetap merasa diawasi oleh Allah, hendaklah selalu mendirikan sholat, kerjakan selalu yang baik dan tinggalkan perbuatan keji, jangan suka menyombongkan diri, sederhanalah dalam berpergian, dan rendahkanlah suaramu.

Walaupun sederhana materi dan metode yang diajarkan Luqman AlHakim kepada putranya termasuk kepada kita semua yang hidup di zaman modern ini, namun betapa cermat dan mendalam filosofi pendidikan serta hikmah yang dimiliki Luqman untuk dapat dipelajari oleh generasi berikutnya sampai akhir jaman. Konsep pendidikan dalam perspektif Al-qur'an yang direfleksikan oleh Allah SWT dalam QS. Luqman (31):12-19.

\section{Hubungan Al-qur'an dengan Manajemen Pendidikan Islam}

Pembicaraan seputar Al-qur'an dan pendidikan tetap menarik, terutama dalam kaitannya dengan upaya membangun sumber daya manusia Muslim yang sesuai dengan nilai-nilai yang terkandung dalam Al-qur'an. Islam sebagai agama yang bersumber pada wahyu Al-qur'an dan sekaligus sebagai pandangan hidup yang diyakini mutlak kebenarannya akan memberikan arah dan landasan etis serta moral pendidikan yang sesuai dengan moralitas Alqur'an.

Islam sebagai agama lahir bersamaan dengan hadirnya manusia pertama, Nabi Adam as. Saat itu pula sebenarnya proses pendidikan Islam dimulai oleh Allah swt. yang mendidik dan membimbing manusia pertama yaitu Adam as. Sebagai subyek didik dengan mengajarkan ilmu pengetahuan berupa nama-nama benda yang tidak diajarkan kepada makhluk selainnya termasuk kepada malaikat sekalipun. ${ }^{11}$ Peristiwa ini terekam dalam Al-qur'an surat al-Baqarah [2] ayat 31 sebagai berikut:

$$
\begin{aligned}
& \rightarrow \text { 回(10\& } 8
\end{aligned}
$$

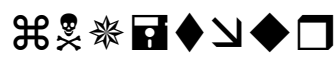

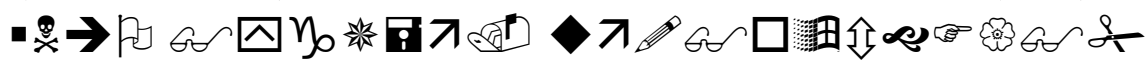

${ }^{10}$ Fatah yasin, Dimensi-Dimensi Pendidikan Islam, (Malang: UIN Malang Press, 2008), hal. 30

${ }^{11}$ Acmadi, Ideologi Pendidikan Islam; Paradigma Humanisme Teosentris, Yogyakarta: Pustaka Pelajar, 2010, hal. 17. 

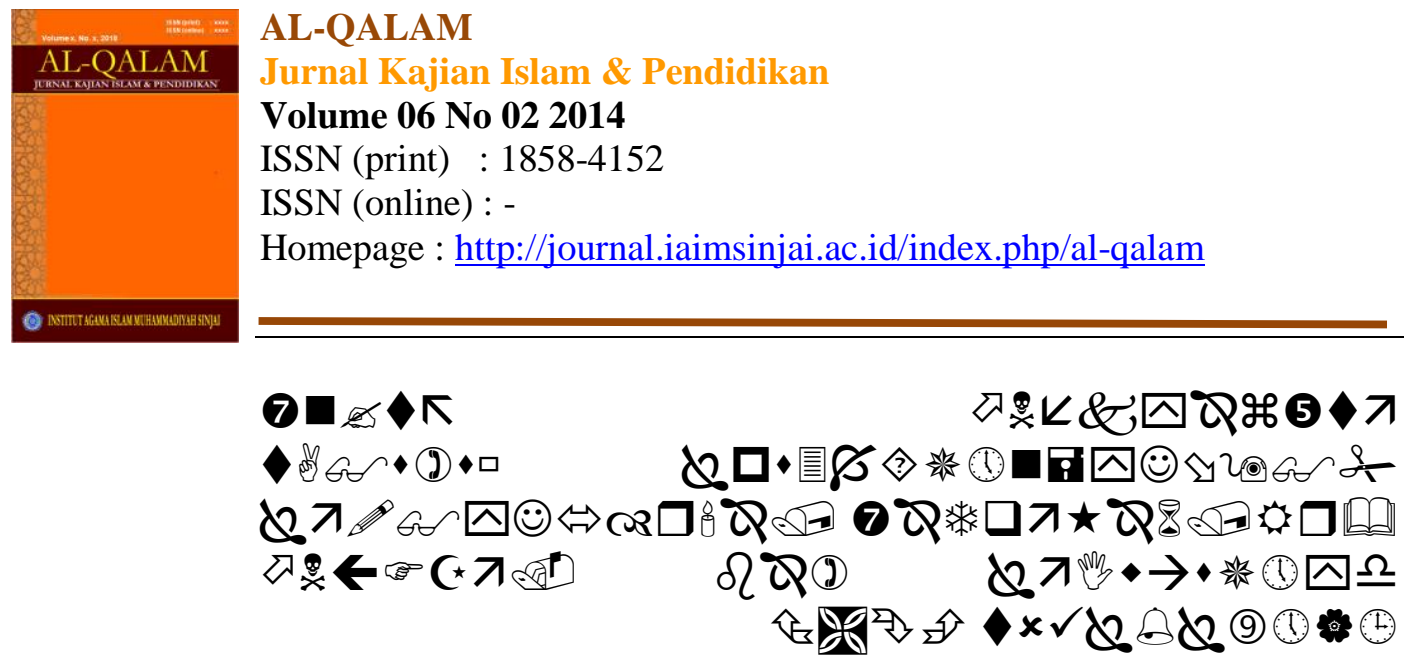

"Dan Dia mengajarkan kepada Adam nama-nama (benda-benda) seluruhnya, kemudian mengemukakannya kepada para malaikat lalu berfirman: "Sebutkanlah kepada-Ku nama benda-benda itu jika kamu mamang benar orang-orang yang benar." (QS. alBaqarah [2]: 31)

Selain itu Allah swt. juga memberikan bimbingan "norma kehidupan" untuk memelihara harkat dan martabat manusia dalam wujud larangan mendekati pohon terlarang. ${ }^{12}$ Peristiwa ini terekam dalam Al-qur'an surat alBaqarah [2] ayat 35 sebagai berikut:

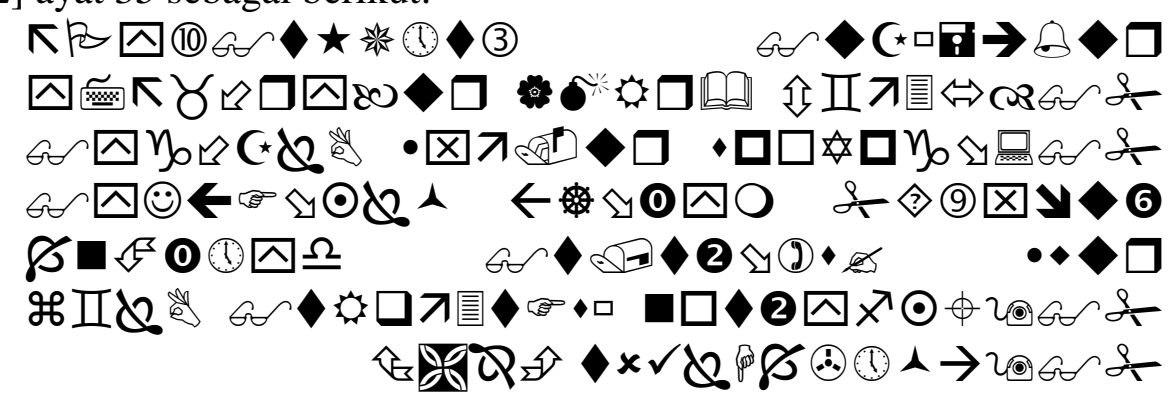

"Dan kami berfirman: "Hai Adam, diamilah oleh kamu dan isterimu surga ini, dan makanlah makanan-makanannya yang banyak lagi baik dimana saja yang kamu sukai, dan janganlah kamu dekati pohon ini, yang menyebabkan kamu termasuk orangorang yang zalim." (QS. al-Baqarah [2]: 35)

Islam yang sekarang ini adalah wahyu Allah swt. yang diturunkan kepada Nabi Muhammad saw. untuk mendidik umat manusia dengan prinsipprinsip ajaran yang sama dengan yang dibawa oleh para nabi terdahulu yaitu ajaran Tauhid yang hanya mengesakan Allah swt. dan beribadah kepada-Nya. Secara keseluruhan ajaran yang dibawa Nabi Muhammad saw. merupakan kesinambungan, kelengkapan, dan penyempurnaan ajaran para nabi terdahulu. Semua itu merupakan satu sistem keyakinan dan ketentuan Ilahi yang merupakan pedoman hidup dalam seluruh aspek kehidupan, baik hubungan manusia dengan Tuhan, dengan sesama manusia, dan dengan alam sekitar. Itulah risalah islamiyah yang merupakan misi Al-qur'an diturunkan dengan satu tujuan untuk mewujudkan rahmat bagi seluruh alam (rahmatan li al-

12 Acmadi, Ideologi Pendidikan Islam; Paradigma Humanisme Teosentris, Yogyakarta: Pustaka Pelajar, 2010, hal. 17. 


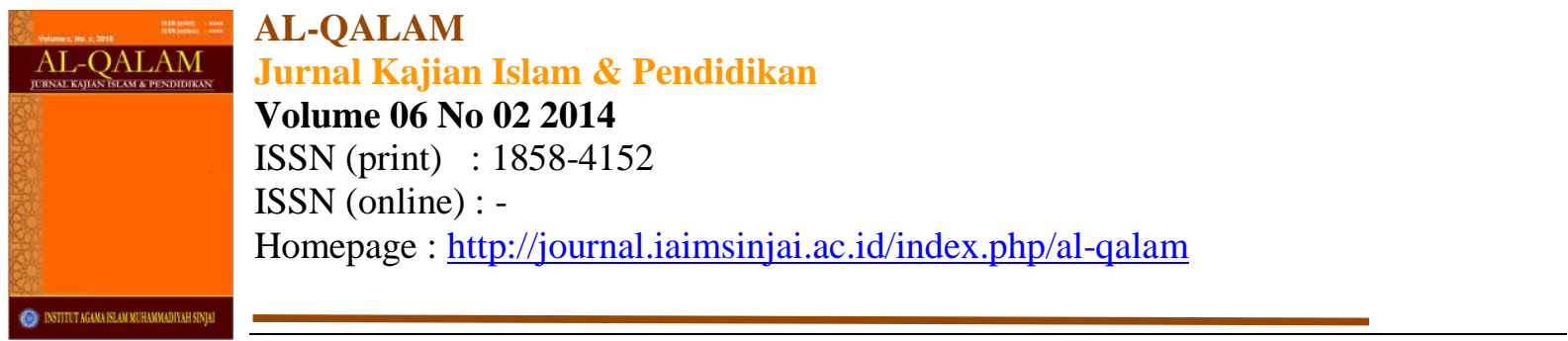

'alamin) ${ }^{13}$ sebagaimana firman Allah swt. dalam Al-qur'an surat al-Anbiya' [21] ayat 107 sebagai berikut:
• पर(ग) क(1) (1)

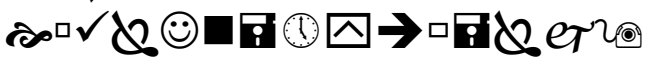

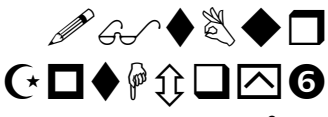

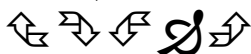
"Dan tiadaklah kami mengutus kamu, melainkan untuk (menjadi) rahmat bagi semesta alam." (QS. al-Anbiya' [21]: 107)

Tidak sedikitpun nilai-nilai ajaran dalam Al-qur'an yang menghambat kemajuan. ${ }^{14}$ Ajaran Islam sebagai pedoman hidup yang sifatnya universal dan eternal tentu tidak mungkin bersifat rinci dan detil, mengingat kompleksitasnya masalah dan perubahan tatangan hidup yang dihadapi manusia dari waktu ke waktu yang tidak dapat diprediksi. Oleh karena itu, yang pada hakekatnya sesuai dengan fitrah manusia hanya memberikan pedoman hidup yang bersifat fundamental dengan nilai-nilai transendental yang memang sesuai dan menjadi kebutuhan hidup manusia. Pedoman hidup yang sifatnya baku dan operasional hanyalah yang berkenaan dengan akidah dan ibadah mahdhah (khusus) sehingga tidak perlu kreatifitas manusia untuk menciptakan pedoman baru. Sedangkan hal-hal yang berkenaan dengan muamalah duniawiyah Islam hanya memberikan pedoman yang berupa nilai-nilai yang implementasinya sebagian besar diserahkan pada manusia. Kalau disebut sebagian besar yang diserahkan pada kreativitas manusia tentu ada bagian lain yang bukan wilayah kreativitas manusia. Hal ini didasarkan atas pandangan mengenai adanya dalil yang qath' $i$ (pasti penunjukannya) yang tidak memerlukan peran ijtihad manusia dan adanya dalil yang wadh' $i$ (tidak pasti penunjukannya) yang memerlukan peran ijtihad manusia dalam merumuskan suatu ketentuan syar'i. ${ }^{15}$

Semangat Al-qur'an adalah semangat kemajuan dan berperadaban. Alqur'an menekankan bahwa kemajuan tidak datang begitu saja dan tidak akan terjelma dengan sendiri tanpa aktivitas. Al-qur'an menekankan perlunya kreatifitas bilamana ingin menjadi bangsa atau umat yang maju, maka sebenarnya tidak ada pilihan lain kecuali mengikuti Al-qur'an dengan cara menggali isyarat-isyarat $\mathrm{Al}$-qur'an baik yang tersurat maupun ayat-ayat yang tersirat. $^{16}$

Islam bukanlah sistem kehidupan yang praktis dan baku, melainkan sebuah sistem nilai dari norma-norma dan moralitas Al-qur'an yang secara

\footnotetext{
13 Ibid: 18.

${ }^{14}$ Sulistyorini, Manajemen Pendidikan Islam; Konsep, Strategi dan Aplikasi, Yogyakarta: Penerbit TERAS, 2009, hal. 3.

${ }^{15}$ Acmadi, Ideologi Pendidikan Islam; Paradigma Humanisme Teosentris, Yogyakarta: Pustaka Pelajar, 2010, hal. 18.

16 Said Agil Husain Al Munawar, Aktualisasi Nilai-nilai Qur'ani dalam Sistem Pendidikan Islam, Ciputat: PT. Ciputat Press, 2005, hal. 17.
} 


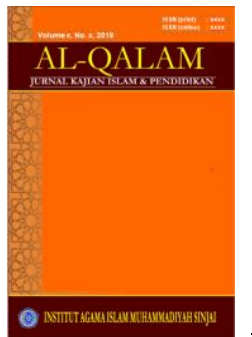

AL-QALAM

Jurnal Kajian Islam \& Pendidikan

Volume 06 No 022014

ISSN (print) : 1858-4152

ISSN (online) : -

Homepage : http://journal.iaimsinjai.ac.id/index.php/al-qalam

dinamis harus dipahami dan diterjemahkan berdasarkan setting sosial, dimensi ruang, dan dimensi waktu tertentu. Karena itu, secara praktis, dalam Al-qur'an tidak terdapat sistem ekonomi, politik, dan pendidikan secara tersurat dan baku. Akan tetapi, manusia dalam hal ini umat Islam yang diberi beban sebagai khalifah di muka bumi diperintahkan untuk membangun sebuah sistem kehidupan praktis dalam segala aspeknya dalam rangka mengamalkan nilainilai dan norma-norma Islam dalam kehidupan nyata. Karena itu, dalam Alqur'an hanya terdapat pilar-pilar penyangga tegaknya sistem pendidikan Islam, seperi tauhid sebagai dasar pendidikan, konsep manusia yang melahirkan dan memberi konsep manajerial tentang pencapaian tujuan pendidikan, dan konsep tentang ilmu yang merupakan isi baru proses pendidikan. ${ }^{17}$

Suatu hal yang penting bagi umat Islam adalah kemampuan untuk terus-menerus menyegarkan pemahaman terhadap Al-qur'an. Dengan cara ini, tidak diragukan lagi bahwa Al-qur'an akan tetap memiliki fungsi sebagai pedoman hidup bagi umat Islam dimanapun posisi berada untuk masa sekarang dan masa yang akan datang. Namun demikian, diperlukan sikap waspada terhadap timbulnya bahaya pemahaman Al-qur'an secara sempit dan kaku yang dapat berakibat hilangnya relevansi ajaran Al-qur'an dengan kenyataan hidup yang dihadapi. 18

Manajemen pendidikan Islam termasuk wilayah muamalah duniawiyah, maka menjadi tugas manusia untuk memikirkannya terus-menerus seirama dengan perkembangan zaman. Prinsip-prinsip manajemen pendidikan Islam telah dilaksanakan oleh Nabi Muhammad saw. dan telah terlihat hasilnya karena beliau mampu mengkomunikasikan Islam agama fitrah dengan fitrah manusia. Zaman terus berkembang, persepsi manusiapun terus mengalami perubahan sejalan dengan tantangan yang dihadapi. Disinilah lahan garapan yang menuntut para praktisi pendidikan Muslim untuk menyusun konsep manajemen pendidikan Islam yang selalu relevan dengan perubahan zaman dan mampu menatap masa depan berdasarkan nilai-nilai dasar Al-qur'an. Karena itu, tegaknya sistem pendidikan Islam merupakan kawasan ijtihad yang dibangun berdasarkan moralitas Al-qur'an. ${ }^{19}$

Dengan kata lain, dalam hal manajemen pendidikan Islam ini, Islam hanya menyediakan bahan baku, sedangkan untuk menjadi sebuah sistem yang operasional, para pakar dan praktisi pendidikan Islam diberikan kebebasan untuk membangun dan menerjemahkannya sesuai dengan kebutuhan dan tuntutan zaman. Karenaya, tidak ada blue print manajemen pendidikan Islam

${ }^{17}$ Sulistyorini, Manajemen Pendidikan Islam; Konsep, Strategi dan Aplikasi, Yogyakarta: Penerbit TERAS, 2009, hal. 21.

18 Said Agil Husain Al Munawar, Aktualisasi Nilai-nilai Qur'ani dalam Sistem Pendidikan Islam, Ciputat: PT. Ciputat Press, 2005, hal. 19.

${ }^{19}$ Acmadi, Ideologi Pendidikan Islam; Paradigma Humanisme Teosentris, Yogyakarta: Pustaka Pelajar, 2010, hal. 19.

Al-Qalam | Volume 6 Nomor 2, 2014

Page 138 


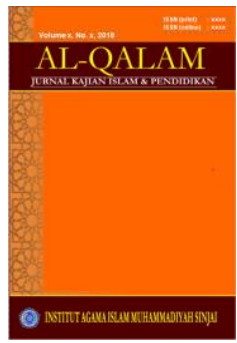

AL-QALAM

Jurnal Kajian Islam \& Pendidikan

Volume 06 No 022014

ISSN (print) : 1858-4152

ISSN (online) : -

Homepage : http://journal.iaimsinjai.ac.id/index.php/al-qalam

yang baku, melainkan para pemerhati pendidikan Islam dirangsang untuk menciptakan sistem manajemen pendidikan Islam yang paling ideal yang sesuai dengan tuntutan zaman. ${ }^{20}$

Dengan cara demikian, maka manajemen pendidikan Islam dapat dilihat sebagai sebuah sistem yang dapat dikembangkan sepanjang zaman dan tidak pernah mengenal batas akhir waktu. Manajemen pendidikan Islam akan selalu aktual dan responsif terhadap berbagai perkembangan yang terjadi di masyarakat. Namun, paradigma ini membawa akibat kepada para pemerhati pendidikan Islam untuk secara terus-menerus menggali Al-qur'an dalam kaitannya dengan berbagai masalah yang terus berkembang dan sedemikian kompleks.

Hal yang harus dicermati oleh para pakar dan praktisi pendidikan Islam adalah dengan adanya tantangan dan hambatan yang serius bagi manajemen lembaga-lembaga pendidikan Islam dewasa ini, terdapat suatu fenomena baru berupa terjadinya berbagai macam perubahan besar di bidang sosial budaya, politik, ekonomi, dan teknologi berskala global, nasional, dan lokal yang memiliki dampak yang sangat dahsyat terhadap eksistensi semua lembaga pendidikan Islam. 21

Perubahan di bidang sosial budaya yang ditandai dengan terjadinya pergeseran dari masyarakat modernis menuju masyarakat post-modernis, dari basis meterial kebudayaan manufacture ke machinofacture, dari teknologi industri ke teknologi informasi, perubahan ekonomi yang ditunjukkan dengan adanya pergantian dari sistem ekonomi sosialis yang tertutup menjadi sistem kapitalis yang menekankan pada sistem pasar terbuka, dan perubahan politik yang diindikasikan dengan bangkitnya kembali sistem politik demokratis di hampir seluruh negara di dunia. Kesemuanya itu, memicu munculnya berbagai macam tuntutan publik terhadap para pengelola lembaga-lembaga pendidikan, tidak terkecuali, terhadap manajemen pendidikan Islam. ${ }^{22}$

Adapun tuntutan publik kepada para pengelola lembaga Pendidikan Islam adalah adanya tuntutan peningkatan kualitas produk, kualitas pelayanan, akuntabilitas, responsivitas, dan penerapan nilai-nilai dan hak-hak dasar manusia dalam organisasi, kebebasan, persamaan, kompetisi, seleksi yang adil, jaminan dibelakukannya peraturan secara fair, pemberdayaan, otonomi,

${ }^{20}$ Sulistyorini, Manajemen Pendidikan Islam; Konsep, Strategi dan Aplikasi, Yogyakarta: Penerbit TERAS, 2009, hal. 21.

${ }^{21}$ Winarno Surakhmad, dkk, Reformasi Pendidikan Muhammadiyah Suatu Keniscayaan, Yogyakarta: Pustaka Suara Muhammadiyah, 2003, hal. 149.

${ }^{22}$ Ibid: 150. 


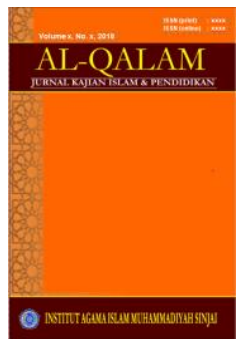

AL-QALAM

Jurnal Kajian Islam \& Pendidikan

Volume 06 No 022014

ISSN (print) : 1858-4152

ISSN (online) : -

Homepage : http://journal.iaimsinjai.ac.id/index.php/al-qalam

partisipasi, dan kontrol publik terhadap manajemen lembaga pendidikan Islam yang transparan. ${ }^{23}$

Peroalan yang kemudian menyusul seiring dengan munculnya berbagai tuntutan publik terhadap para pengelola lembaga-lembaga pendidikan Islam antara lain ialah bagaimanakah mereka harus mempertahankan eksistensi lembaga pendidikan Islam dalam situasi perubahan lingkungan yang sangat tidak menentu? Bagaimanakah mereka mesti merespon, mengadaptasi, dan mengantisipasi segala perubahan yang serba tidak menentu tersebut? Dan secara keseluruhan bagaimanakah mereka harus berinovasi dan merekonstruksi manajemen lembaga pendidikan Islam agar mampu meningkatkan kinerjanya sehingga mampu beradaptasi dengan perubahan lingkungan baru. ${ }^{24}$

Tugas ini pada gilirannya akan memaksa para pakar dan praktisi pendidikan Islam untuk terus melakukan pengembangan kajian dan penelitian untuk mencari perspektif baru dalam upaya merekonstruksi manajemen pendidikan Islam yang selalu sesuai dengan perkembangan dan kebutuhan zaman. Akibatnya, jika tugas ini tidak direspon secara proporsional, maka tidak mustahil lembaga-lembaga pendidikan Islam akan mulai dijauhi publik dan Alqur'an akan ditinggalkan para penganutnya dan dinilai sebagai barang kuno yang sekedar menjadi perhiasan atau lebih tidak menguntungkan lagi menjadi barang yang telah usang karena ajarannya dinilai tidak mampu bernilai fungsional. $^{25}$

\section{Fungsi Manajemen Pendidikan Islam}

Islam dalam perjalanan sejarahnya tidak selalu memainkan peran ideal dan determinan bagi pemeluknya. Dalam rangka menghadapi realitas sosial dan kultural, Islam tidak selalu mampu memberikan jawaban seperti yang diharapakn para pemeluknya. Kenyataan ini banyak terkait dengan sifat ilahiyah dan transendensi Islam berupa ketentuan-ketentuan yang normatifdogmatif. Pada ranah ini sering terjadi semacam "pertarungan teologis" antara keharusan berpegang teguh dengan doktrin yang bersifat normatif dengan keinginan memberikan pemaknaan baru terhadap doktrin tersebut agar nampak historisitasnya. Pertarungan ini pada gilirannya memunculkan konflik teologis, intelektual, dan sosial di kalangan kaum Muslim secara merata. Kenyataan inilah yang di antaranya mewarnai munculnya berbagai gerakan pembaruan

${ }^{23}$ Winarno Surakhmad, dkk, Reformasi Pendidikan Muhammadiyah Suatu Keniscayaan, Yogyakarta: Pustaka Suara Muhammadiyah, 2003, hal. 150.

${ }^{24}$ Ibid.

${ }^{25}$ Sulistyorini, Manajemen Pendidikan Islam; Konsep, Strategi dan Aplikasi, Yogyakarta: Penerbit TERAS, 2009, hal. 22. 


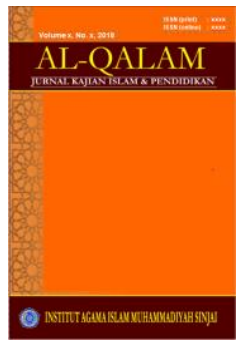

dalam Islam melalui jalur pendidikan untuk menjdiakan Islam berwajah lebih membumi. ${ }^{26}$

Sejarah menunjukkan bahwa pendidikan merupakan program pokok yang sangat strategis dalam melaksanakan gerakan pembaruan dalam Islam. Fungsi pendidikan dalam hal ini kiranya bukan hanya untuk menghilangkan buta huruf atau membentuk watak suatu masyarakat. Lebih dari itu, melalui pendidikan diharapkan dapat terjadi perubahan-perubahan dalam segala bidang. Oleh karena itu, tidak jarang sebuah gerakan pembaruan selalu menjadikan bidang pendidikan sebagai target utamanya. Keberhasilan dalam bidang ini akan menentukan keberhasilan dalam bidang-bidang pembaruan lainnya. ${ }^{27}$

Universalitas ajaran Islam yang selalu menuntut diaktualisasikannya nilai-nilai Islami dalam kehidupan nyata merupakan pokok sekaligus pangkal perlunya dilakukannya pembaruan dalam bidang pendidikan. Hal ini terutama setelah terjadinya kontak Islam dengan dunia Barat pada akhir abad ke-18 M. gerakan pembaruan Islam dengan segala bentuk dan coraknya, mulai dari yang konservatif, reformis, sekuler hingga fundamentalis, mempunyai implikasi yang sangat massif bagi proses berlangsungnya pembaruan dalam bidang pendidikan. Bagaimanaun juga, suatu bentuk pembaruan tentunya memerlukan sebuah wadah dan strategi tertentu dalam rangka tercapainya tujuan pembaruan yang diharapkan. Dalam hal ini, pendidikan kiranya menduduki posisi yang sangat strategis untuk dijadikan sebagai wahana dalam keberlangsungan pembaruan. $^{28}$

Dalam perkembangan gerakan pembaruan Islam, pembaruan dalam bidang pendidikan tidak terlepas dari aspek manajerial lembaga pendidikan Islam. Keberadaan konsep manajemen pendidikan Islam yang inovatif, kreatif, efektif, dan efisien merupakan dasar bagi keberlangsungan lembaga-lembaga pendidikan Islam sebagai wadah bagi aplikasi dan implementasi dari suatu citacita pembaruan Islam. Oleh karena itu, aspek manajerial pendidikan Islam dalam upaya pembaruan pendidikan Islam sebagai wadah aplikasi dan implementasi pembaruan Islam merupakan tiga hal yang tidak dapat dipisahkan. Pembaruan pendidikan Islam melalui aspek manajerial dalam tingkat kelembagaan pendidikan Islam pada dasarnya merupakan manifestasi bagi pembaruan Islam itu sendiri. ${ }^{29}$

Aspek manajemen pendidikan Islam yang berhubungan dengan usaha untuk tujuan tertentu dengan jalan menggunakan berbagai sumber daya

26 Toto Suharto, dkk, Rekonstruksi dan Modernisasi Lembaga Pendidikan Islam, Yogyakarta: Global Pustaka Utama Yogyakarta, 2005, hal. 3.

${ }^{27}$ Ibid: 15.

${ }^{28}$ Ibid: 16.

29 Toto Suharto, dkk, Rekonstruksi dan Modernisasi Lembaga Pendidikan Islam, Yogyakarta: Global Pustaka Utama Yogyakarta, 2005, hal. 16. 


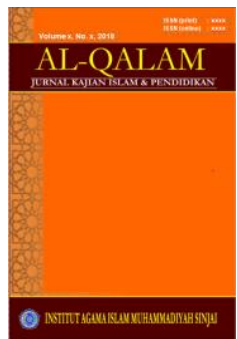

AL-QALAM

Jurnal Kajian Islam \& Pendidikan

Volume 06 No 022014

ISSN (print) : 1858-4152

ISSN (online) : -

Homepage : http://journal.iaimsinjai.ac.id/index.php/al-qalam

yang tersedia dalam sebuah organisasi atau lembaga pendidikan Islam dengan cara sebaik mungkin merupakan sebuah upaya dalam melakukan pembaruan lembaga pendidikan Islam. Manajemen bukan hanya mengatur tempat melainkan lebih dari itu, yaitu mengatur orang per orang. Dalam mengatur orang, diperlukan seni dengan sebaik-baiknya sehingga kepala sekolah yang baik adalah kepala sekolah yang mampu menjadikan setiap tenaga kependidikan atau non kependidikan yang ada dalam sebuah lembaga pendidikan Islam mampu menikmati pekerjaan mereka. Jika setiap individu mampu menikmati pekerjaannya, hal ini menandakan keberhasilan kepala sekolah dalam hal manajemen lembaga tersebut. ${ }^{30}$

Di dalam proses manajemen digambarkan fungsi-fungsi manajemen yang ditampilkan ke dalam perangkat organisasi. Para ahli mengabstraksikan proses manajemen menjadi menjadi 4 proses. Yaitu, planning, organizing, actuating, dan controlling (PAOC). Empat proses manajemen ini digambarkan dalam bentuk siklus karena adanya saling keterkaitan antara proses yang pertama dan berikutnya, begitu juga setelah pelaksanaan controlling lazimnya dilanjutkan dengan membuat planning baru hingga siklus proses manajemen akan selalu berputar. ${ }^{31}$ Dalam hal ini para pakar manajemen pendidikan Islam merumuskan siklus proses manajemen pendidikan Islam sebagai berikut:

\section{a. Perencanaan (Planning) Pendidikan Islam}

Perencanaan pada hakikatnya memiliki pengertian sebagai sebuah proses pengambilan keputusan atas sejumlah alternatif dari beberapa pilihan mengenai sasaran dan cara-cara yang akan direalisasikan di masa yang akan datang guna mencapai tujuan pendidikan yang dikehendaki agar pelaksanaan dapat berjalan dengan baik, sistematis, tidak tumpang tindih, dan tidak ada yang terlewatkan. ${ }^{32}$

Menurut Husaini Usman perencanaan tidak dapat dipisahkan dari unsur pelaksanaan, pengawasan, pemantauan, penilaian dan pelaporan agar tidak terjadi penyimpangan-penyimpangan. Pada prinsipnya pengawasan dalam perencanaan dapat dilakukan secara preventif maupun represif. Prefentif merupakan pengawasan yang melekat dengan perencanaan itu sendiri, sedangkan pengawasan represif merupakan pengawasan fungsional atas pelaksanaan rencana, baik yang dilakukan secara internal maupun secara eksternal oleh aparat pengawas yang ditugasi. ${ }^{33}$

${ }^{30}$ Sulistyorini, Manajemen Pendidikan Islam; Konsep, Strategi dan Aplikasi, Yogyakarta: Penerbit TERAS, 2009, hal. 26.

${ }^{31}$ Ibid: 27.

${ }^{32}$ Husaini Usman, Manajemen; Teori, Praktek dan Riset Pendidikan, Jakarta: PT. Bumi Aksara, 2008, hal. 61.

${ }^{33}$ Husaini Usman, Manajemen; Teori, Praktek dan Riset Pendidikan, Jakarta: PT. Bumi Aksara, 2008, hal. 61. 


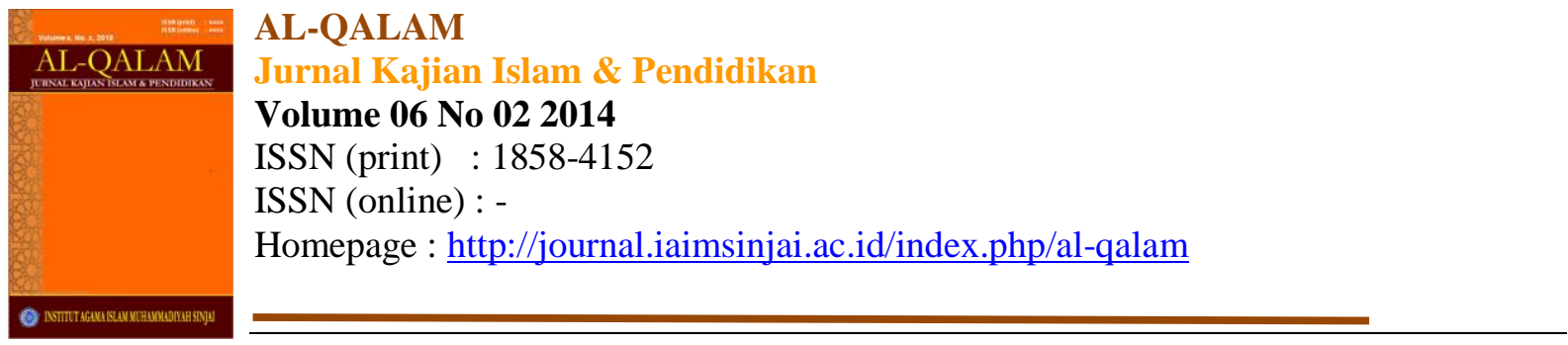

Nilai-nilai manajerial ini juga terdapat dalam Al-qur'an maupun hadis baik secara tegas maupun sindiran. Kewajiban untuk membuat perencanaan yang teliti sebelum melaksanakan suatu pekerjaan merupakan nilai-nilai moralitas yang terdapat dalam Al-qur'an ataupun hadis sebagai ajaran yang diwajibkan.

Salah tujuan perencanaan adalah untuk mendeteksi hambatan dan kesulitan yang akan ditemui agar dapat menghindari kesalahan-kesalahan yang dimungkinkan akan terjadi dalam menggapai suatu tujuan yang telah dicanangkan. ${ }^{34}$ Salah satu ajaran Al-qur'an adalah adanya nilai-nilai perencanaan pada aspek manajemen dengan adanya kewajiban untuk bersikap hati-hati dalam melaksanakan suatu pekerjaan. Hal ini diwujudkan dengan mendeteksi hambatan-hambatan dan kesulitan-kesulitan untuk menghindari kesalahan-kesalahan yang dimungkinkan akan terjadi dalam menggapai suatu tujuan. Nilai perencanaan tersebut terdapat dalam firman Allah swt. dalam surat al-Maidah [5] ayat 92 sebagai berikut :

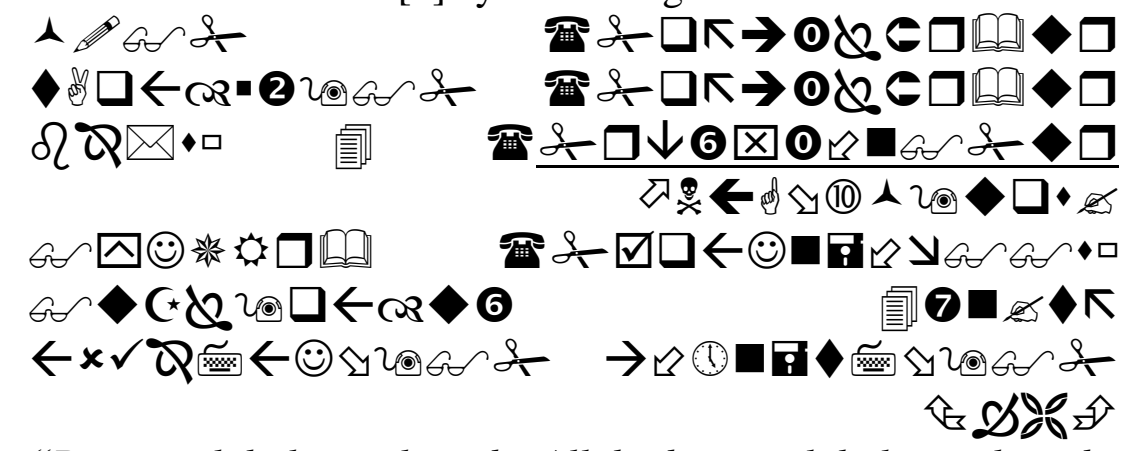

"Dan taatlah kamu kepada Allah dan taatlah kamu kepada Rasul-(Nya) dan berhati-hatilah. Jika kamu berpaling, maka ketahuilah bahwa sesungguhnya kewajiban Rasul kami, hanyalah menyampaikan (amanat Allah) dengan terang. " (QS. al-Maidah [5]: 92)

Proses manajemen pada dasarnya adalah perencanaan segala sesuatu secara sistematis yang kemudian akan melahirkan keyakinan yang berdampak pada melakukan sesuatu yang sesuai dengan aturan serta memiliki manfaat. Perbuatan yang tidak bernilai manfaat adalah sama dengan perbuatan yang tidak pernah direncanakan. Jika perbuatan tersebut tidak pernah direncanakan, maka dapat dipastikan dalam pelaksanaannya akan menemui berbagai hambatan dan kesulitan dalam proses penyelesaian masalah tersebut. ${ }^{35}$

${ }^{34}$ Ibid: 60.

${ }^{35}$ Sulistyorini, Manajemen Pendidikan Islam; Konsep, Strategi dan Aplikasi, Yogyakarta: Penerbit TERAS, 2009, hal. 28. 


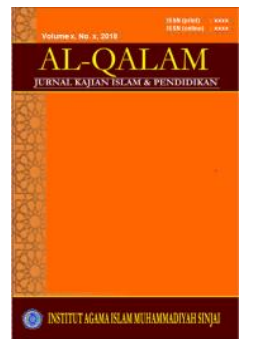

AL-QALAM

Jurnal Kajian Islam \& Pendidikan

Volume 06 No 022014

ISSN (print) : 1858-4152

ISSN (online) : -

Homepage : http://journal.iaimsinjai.ac.id/index.php/al-qalam

Perencanaan merupakan suatu proses berpikir. Tuhan memberikan akal dan ilmu guna melakukan sebuah ikhtiar, untuk menghindari kerugian dan kegagalan sekaligus sebagai wujud sikap kehati-hatian sebagaimana firman Allah swt. dalam QS. al-Maidah [5] ayat 92 tersebut di atas. Ini berarti bahwa semua pekerjaan harus dimulai dengan perencanaan. Ikhtiar disini adalah sebagai perwujudan dari proses berpikir yang merupakan perwujudan dari suatu perencanaan. ${ }^{36}$

1) Tujuan Perencanaan Pendidikan Islam

Tujuan perencanaan pendidikan menurut Husaini Usman ada sembilan, yaitu: ${ }^{37}$

a) Standar pengawasan, yaitu mencocokkan pelaksanaan dengan perencanaannya

b) Mengetahuai kapan pelaksanaan dan selesainya suatu kegiatan

c) Mengetahui struktur organisasinya baik kualifikasinya maupun kuantitasnya

d) Mendapatkan kegiatan yang sisiematis ternasuk biaya dan kualitas kegiatan

e) Meminimalkan kegiatan-kegiatan yang tidak produktif dan dapat menghemat biaya, tenaga, dan waktu

f) Memberikan gambaran yang menyeluruh mengenai kegiatan dalam proses pendidikan

g) Menyerasikan dan memadukan beberapa subkegiatan pendidikan

h) Mendeteksi hambatan kesulitan yang bakal ditemui dalam proses pendidikan

i) Mengarahkan pada pencapaian tujuan pendidikan

2) Manfaat Perencanaan Pendidikan Islam

Adapun manfaat perencanaan pendidikan menurut Husaini Usman ada tujuh, yaitu: ${ }^{38}$

a) Standar pelaksanaan dan pengawasan pendidikan

b) Pemilihan berbagai alternatif terbaik

c) Penyusunan skala prioritas, baik sasaran maupun proses pendidikan

d) Menghemat pemanfaatan sumber organisasi

e) Membantu manajer/pelaksana menyesuaikan diri dengan perubahan lingkungan

${ }^{36}$ Ibid: 29.

${ }^{37}$ Husaini Usman, Manajemen; Teori, Praktek dan Riset Pendidikan, Jakarta: PT. Bumi Aksara, 2008, hal. 60.

${ }^{38}$ Husaini Usman, Manajemen; Teori, Praktek dan Riset Pendidikan, Jakarta: PT. Bumi Aksara, 2008, hal. 60. 


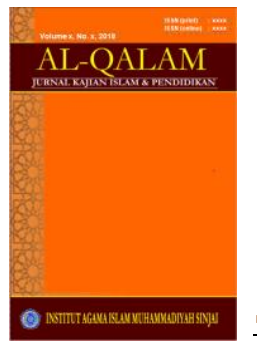

f) Sarana (alat) yang memudahkan dalam berkoordinasi dengan pihak terkait

g) Alat meminimalkan kerja pendidikan yang tidak pasti

\section{b. Pengorganisasian (Organizing) Pendidikan Islam}

Pengorganisasian adalah suatu mekanisme atau suatu struktur, yang dengan struktur itu semua subyek, perangkat lunak dan perangkat keras yang kesemuanya dapat bekerja secara efektif, dan dapat dimanfaatkan menurut fungsi dan proporsinya masing-masing. Adanya inisiatif, sikap yang kreatif dan produktif dari semua anggota organisasi pendidikan Islam dari pangkat yang paling rendah sampai yang tertinggi akan menjamin organisasi pendidikan Islam berjalan dengan baik. ${ }^{39}$

Dalam Al-qur'an terdapat beberapa ayat yang dengan tegas menunjukkan tentang pentingnya memberikan porsi job discription yang tepat dalam melaksanakan suatu tugas. Nilai-nilai pengorganisasian tersebut terdapat dalam Al-qur'an surat al-An'am [6] ayat 132 dan surat at-Taubah [9] ayat 105 sebagai berikut: ${ }^{40}$

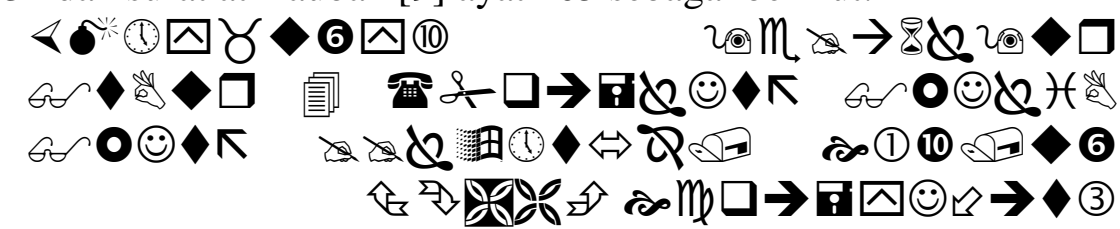

"Dan masing-masing orang memperoleh derajat-derajat (seimbang) dengan apa yang dikerjakannya. dan Tuhanmu tidak lengah dari apa yang mereka kerjakan.” (QS. al-An'am [6]: 132)

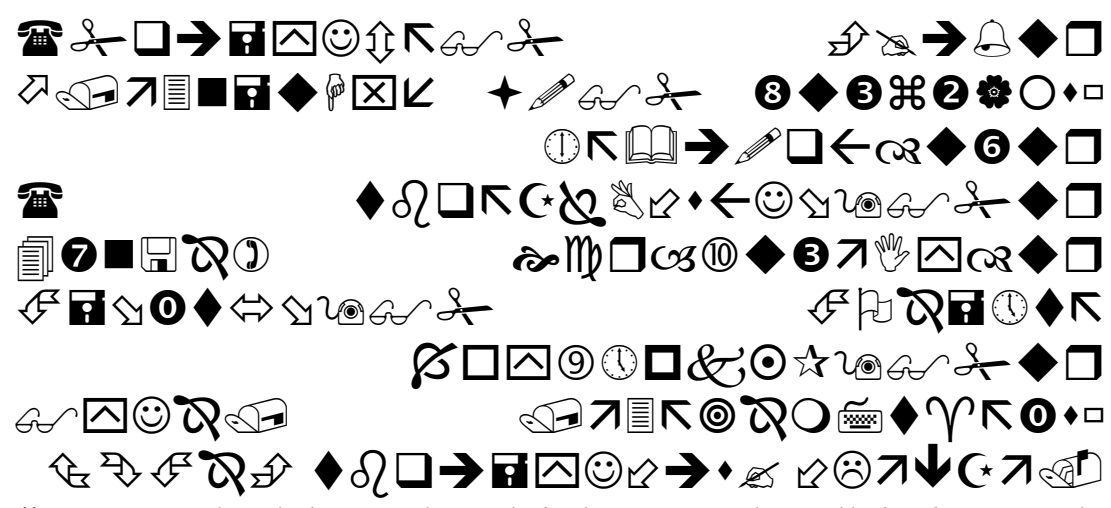

"Dan Katakanlah: "Bekerjalah kamu, maka Allah dan rasulNya serta orang-orang mukmin akan melihat pekerjaanmu itu, dan kamu akan dikembalikan kepada (Allah) yang mengetahui

${ }^{39}$ Sulistyorini, Manajemen Pendidikan Islam; Konsep, Strategi dan Aplikasi, Yogyakarta: Penerbit TERAS, 2009, hal. 29.

${ }^{40}$ Ibid: 30. 


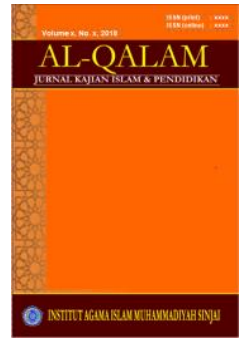

AL-QALAM

Jurnal Kajian Islam \& Pendidikan

Volume 06 No 022014

ISSN (print) : 1858-4152

ISSN (online) : -

Homepage : http://journal.iaimsinjai.ac.id/index.php/al-qalam

akan yang ghaib dan yang nyata, lalu diberitakan-Nya kepada

kamu apa yang telah kamu kerjakan." (QS. at-Taubah [9]: 105)

Dalil-dalil tersebut di atas yang dengan tegas dan jelas menunjukkan bahwa manusia dalam prakteknya berkarya menurut kecakapan masing-masing. Kecakapan seseorang baik berupa ilmu yang dipunyainya maupun sebagai pengalaman akan menempatkan seseorang pada posisi tertentu sesuai dengan disiplin ilmunya. Pembagian kerja semacam ini pada akhirnya akan menjurus menjadi spesialisasi dan profesionalisme yang diakibatkan adanya perbedaan kecakapan, perbedaan disiplin ilmu, dan keterampilan masingmasing. 41

Aspek profesionalisme yang merujuk pada sifat dari suatu pekerjaan yang membutuhkan kompetensi atau keahlian teknis. Profesionalisme dalam artian ini merupakan suatu kebutuhan lembaga pendidikan Islam yang modern yang tidak mungkin dapat dihindari lagi karena era perubahan sekarang menyebabkan terjadinya kompleksitas masalah yang ada baik di dalam maupun di luar lembaga pendidikan Islam yang harus mendapat perhatian secara khusus oleh para pengelola lembaga pendidikan Islam. 42

Di dalam manajemen lembaga pendidikan Islam selama ini, dalam hal profesionalisme seringkali mengabaikan planning sumber daya manusia dalam pengorganisasian. Di antaranya dalam hal recruitment yang nepotis, tidak adanya sistem penghargaan dan punisment, minimnya pengadaan training dan motivasi, dan kebutuhan untuk aktualisasi diri dalam lembaga nampaknya nyaris tidak diperhatikan dan tidak dianggap sebagai suatu hal yang penting dalam upaya membentuk atmosfer kerja yang kondusif. ${ }^{43}$ Hal lain yang dapat dilakukan oleh lembaga-lembaga pendidikan Islam dalam rangka menciptakan budaya kerja yang sehat adalah dengan merefungsionalisasi sistem pengorganisasian di dalam lembagalembaga pendidikan Islam dengan melakukan rancang bangun ulang

${ }^{41}$ Sulistyorini, Manajemen Pendidikan Islam; Konsep, Strategi dan Aplikasi, Yogyakarta: Penerbit TERAS, 2009, hal. 30.

${ }^{42}$ Winarno Surakhmad, dkk, Reformasi Pendidikan Muhammadiyah Suatu Keniscayaan, Yogyakarta: Pustaka Suara Muhammadiyah, 2003, hal. 154.

${ }^{43}$ Winarno Surakhmad, dkk, Reformasi Pendidikan Muhammadiyah Suatu Keniscayaan, Yogyakarta: Pustaka Suara Muhammadiyah, 2003, hal. 154. 


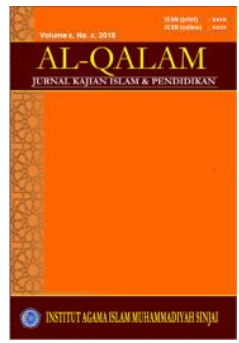

AL-QALAM

Jurnal Kajian Islam \& Pendidikan

Volume 06 No 022014

ISSN (print) : 1858-4152

ISSN (online) : -

Homepage : http://journal.iaimsinjai.ac.id/index.php/al-qalam

pekerjaan untuk menentukan alih tugas, alih wilayah unit kerja, perluasan pekerjaan, dan dengan pembentukan tim kerja otonom. ${ }^{44}$

Dalam sejarah tercatat, bahwa Rasulullah saw. sewaktu membentuk atribut-atribut negara dalam kedudukan beliau sebagai pemegang kekuasaan tertinggi, beliau membentuk organisasi yang didalamnya terlibat para sahabat beliau yang beliau tempatkan pada kedudukan menurut kecakapan dan bidang ilmu masing-masing (profesionalisme). Inilah salah satu contoh pengorganisasian profesional yang dapat menciptakan kerja yang produktif dan pada akhirnya berhasil mengawal sebuah tujuan yang telah dicita-citakan bersama dalam sebuah organisasi. 45

\section{c. Penggerakan (Actuating) Pendidikan Islam}

Penggerakan (actuating) merupakan fungsi manajemen yang komplek dan merupakan ruang lingkup yang cukup luas serta sangat berhubungan erat dengan sumber daya manusia yang pada akhirnya actuating merupakan pusat sekitar aktivitas-aktivitas manajemen. Actuating pada hakekatnya adalah menggerakkan sumber daya manusia untuk mencapai tujuan yang telah ditetapkan secara efektif dan efisien. $^{46}$

Actuating (penggerakkan) merupakan kemampuan seseorang untuk memberikan kegairahan, kegiatan, pengertian, sehingga orang lain mau mendukung dan bekerja dengan suka rela untuk mencapai tujuan organisasi atau lembaga pendidikan Islam yang sesuai dengan tugas yang diberikan kepadanya. ${ }^{47}$ Jika seseorang dapat digerakkan dengan suka rela, dan dapat merasakan bahwa pekerjaan itu adalah kewajiban yang harus dikerjakan dengan suka rela seperti pekerjaanya sendiri dengan disertai adanya rasa memiliki (sense of belonging), ikut bertanggungjawab, akan timbul perasaan kecewa jika gagal, sebaliknya akan timbul perasaan bahagia jika tujuan berhasil dicapai. Maka berarti fungsi motivasi pemimpin telah berhasil. ${ }^{48}$

Fungsi actuating berhubungan erat dengan sumber daya manusia, oleh karena itu seorang pemimpin pada lembaga pendidikan Islam dalam membina kerjasama, mengarahkan dan mendorong

${ }^{44}$ Ibid: 158.

${ }^{45}$ Sulistyorini, Manajemen Pendidikan Islam; Konsep, Strategi dan Aplikasi, Yogyakarta: Penerbit TERAS, 2009, hal. 30.

${ }^{46}$ Ibid: 31.

${ }^{47}$ Ibid.

${ }^{48}$ Sulistyorini, Manajemen Pendidikan Islam; Konsep, Strategi dan Aplikasi, Yogyakarta: Penerbit TERAS, 2009, hal. 31. 


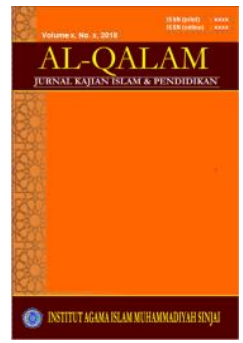

AL-QALAM

Jurnal Kajian Islam \& Pendidikan

Volume 06 No 022014

ISSN (print) : : 1858-4152

ISSN (online) : -

Homepage : http://journal.iaimsinjai.ac.id/index.php/al-qalam

kegairahan kerja sumber daya manusianya perlu memahami faktorfaktor manusia dan pelakunya. Pada suatu lembaga pendidikan Islam, kepemimpinan efektif hendaknya memberikan arah kepada usaha dari semua sumber daya manusia dalam mencapai tujuan lembaga pendidikan Islam. Tanpa adanya kepemimpinan yang efektif, hubungan antara tujuan perseorangan dengan tujuan lembaga bisa mengalami salah orientasi. Hal demikian dapat memicu munculnya situasi terhadap orang-orang yang bekerja untuk mencapai tujuan pribadi, sedang tujuan organisasi tidak dapat tercapai secara efektif. ${ }^{49}$

Penggerakkan (actuating) dilakukan tidak cukup hanya dengan kata-kata manis dan sekedar basa-basi yang diucapkan kepada orang lain. Lebih dari itu, actuating adalah pemahaman mendalam akan berbagai kemampuan, kesanggupan, keadaan, motivasi, dan kebutuhan orang lain. Selanjutnya, menjadikan semua faktor tersebut sebagai sarana penggerak dalam bekerja secara bersama-sama sebagai sebuah kerja tim atau kelompok. Sekaligus berupaya mewujudkan tujuan bersama di dalam situasi yang saling pengertian, saling kerjasama, saling kasih sayang, dan saling mencintai. ${ }^{50}$

Pengembangan manajemen lembaga pendidikan Islam dalam upaya mengoptimalkan aspek actuating ini juga dapat ditempuh dengan restrukturisasi dan refungsionalisasi manajemen lembaga untuk memperlancar proses komunikasi dalam semua aspek struktural lembaga pendidikan. Restrukturisasi dan refungsionalisasi ini mengandung makna sebagai usaha untuk merumuskan kembali pola ataupun struktur lembaga dan hubungan antar unit dalam lembaga, serta sistem atau mekanisme di dalam lembaga dengan menciptakan kembali prosedur dan tata kerja lembaga sedemikian rupa sehingga proses komunikasi antar antar unit kerja, sistem pendelegasian, pemberian wewenang, dan fungsi-fungsi sumber daya manusia dalam lembaga dapat berjalan secara efektif dan efisien. ${ }^{51}$

Dengan demikian, struktur lembaga pendidikan Islam mesti didesain dengan model lingkaran demokrasi yang bersifat pipih dan partisipatif. Dengan model struktur yang makin mendatar diharapkan lembaga pendidikan Islam memiliki rentang kendali yang makin melebar dan tingkat-tingkat hirarki dapat terkurangi, sehingga proses komunikasi antar struktur bisa lebih lancar. Di samping itu, dengan rentang kendali yang makin melebar, unit-unit kerja atau tim kerja fungsional dalam lembaga dapat memiliki otonomi yang lebih luas

${ }^{49} \mathrm{Ibid}: 32$.

${ }^{50}$ Ibid.

${ }^{51}$ Winarno Surakhmad, dkk, Reformasi Pendidikan Muhammadiyah Suatu Keniscayaan, Yogyakarta: Pustaka Suara Muhammadiyah, 2003, hal. 157. 


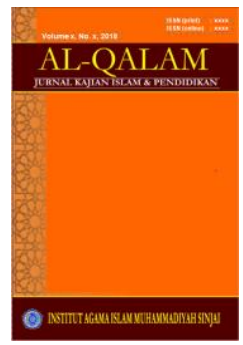

AL-QALAM

Jurnal Kajian Islam \& Pendidikan

Volume 06 No 022014

ISSN (print) : 1858-4152

ISSN (online) : -

Homepage : http://journal.iaimsinjai.ac.id/index.php/al-qalam

untuk melakukan kreativitas dan inovasi bersama yang pada gilirannya dapat menjadi pendorong kemajuan lembaga. ${ }^{52}$

\section{d. Pengawasan (Controlling) Pendidikan Islam}

Pengawasan adalah suatu usaha untuk meneliti kegiatankegiatan yang telah dan akan dilaksanakan. Pengawasan berorientasi pada semua obyek lembaga pendidikan dan merupakan faktor manajemen yang paling penting untuk menuju kepada tujuan yang ingin dicapai. Pengawasan merupakan langkah penentu terhadap apa yang harus dirumuskan dalam aspek perencanaan yang akan dirancang, sekaligus menilai dan memperbaiki, sehingga pelaksanaannya sesuai dengan rencana, serta terwujudnya tujuan secara lebih efektif dan efisien pada masa selanjutnya. ${ }^{53}$

Adapun fungsi pengawasan yaitu sebagai upaya penyesuaian antara rencana yang telah disusun dengan pelaksanaan atau realitas hasil yang benar-benar tercapai. Untuk mengetahui hasil capaian apakah benar-benar telah sesuai dengan rencana yang telah disusun, diperlukan informasi tentang tingkat pencapaian hasil. Informasi tersebut dapat diproleh melalui komunikasi dengan bawahan, khususnya dari laporan-laporan dari setiap unit-unit kerja ataupun dengan melakukan observasi berkala secara langsung dan mendadak. Apabila hasil tidak sesuai dengan standar yang telah ditentukan, pimpinan dapat menggali informasi tentang masalah-masalah yang dihadapi. Dengan demikian tindakan perbaikan dapat disesuaikan dengan sumber masalah. Di samping itu, untuk menghindari kesalahpahaman tentang fungsi pengawasan antara pengawas dengan obyek pengawasan, maka perlu dipelihara jalur komunikasi yang efektif, proporsional, obyektif, bebas dari prasangka buruk, berdayaguna, dan berhasilguna. ${ }^{54}$

Beberapa hal yang dapat dilakukan dalam rangka keefektifan pengawasan adalah dengan mengadakan pemetaan. Pemetaan ini berfungsi terutama untuk kepentingan analisis kebijakan secara menyeluruh dan perumusan perencanaan maupun kebijakan baru pengembangan lembaga pendidikan Islam baik yang bersifat menyeluruh maupun per sektor unit kerja. ${ }^{55}$ Hal lain yang dapat

52 Ibid.

${ }^{53}$ Sulistyorini, Manajemen Pendidikan Islam; Konsep, Strategi dan Aplikasi, Yogyakarta: Penerbit TERAS, 2009, hal. 32.

${ }^{54}$ Sulistyorini, Manajemen Pendidikan Islam; Konsep, Strategi dan Aplikasi, Yogyakarta: Penerbit TERAS, 2009, hal. 33.

${ }^{55}$ Winarno Surakhmad, dkk, Reformasi Pendidikan Muhammadiyah Suatu Keniscayaan, Yogyakarta: Pustaka Suara Muhammadiyah, 2003, hal. 146. 


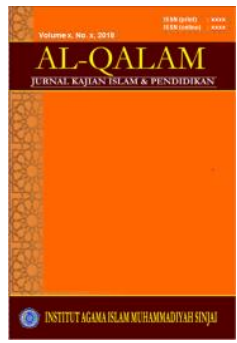

AL-QALAM

Jurnal Kajian Islam \& Pendidikan

Volume 06 No 022014

ISSN (print) : 1858-4152

ISSN (online) : -

Homepage : http://journal.iaimsinjai.ac.id/index.php/al-qalam

dilakukan adalah dengan melihat beberapa aspek dalam lembaga pendidikan untuk dapat mengetahui deskripsi kinerja organisasi secara utuh. Yaitu, aspek produktivitas, kualitas pelayanan, responsivitas, profesionalisme, dan akuntabilitas. ${ }^{56}$

Tujuan penegawasan dalam lembaga pendidikan Islam haruslah positif dan konstruktif, yaitu untuk memperbaiki, mengurangi pemborosan waktu, anggaran, material, dan tenaga di lembaga pendidikan Islam. Di samping itu juga bertujuan untuk membantu menegakkan agar prosedur, program, standar, dan peraturan dapat berjalan sebagaimana mestinya hingga dapat mencapai efisiensi lembaga pendidikan Islam yang setinggi-tingginya. ${ }^{57}$

\section{Substansi Manajemen Pendidikan Islam}

Hal yang harus disadari bahwa sebuah lembaga pendidikan Islam yang baik adalah dengan adanya seni kepemimpinan yang baik, didasari oleh nilainilai filosofis yang diyakininya, dan adanya nilai-nilai profesionalisme. Nilainilai tersebut adalah nilai-nilai yang terdapat dalam Al-qur'an dan nilai-nilai profesionalitas manajerial dalam menangani sistem pendidikan Islam pada tingkat satuan pendidikan sekolah Islam yang menjadi bidang garapannya. ${ }^{58}$

Manajemen pendidikan Islam merupakan manajemen kelembagaan Islam yang bertujuan untuk menunjang perkembangan dan penyelenggaraan proses pembelajaran demi terwujudnya visi dan misi lembaga pendidikan Islam tersebut. Dengan demikian, manajemen pendidikan Islam berkaitan erat dengan penerapan hasil berpikir rasional untuk mengorganisasikan kegiatan yang menunjang kelancaran proses pembelajaran. Kegiatan-kegiatan yang berkaitan dengan dengan kelancaran proses pembelajaran harus direncanakan dan dikelola dengan sebaik mungkin demi tercapainya visi dan misi lembaga pendidikan Islam yang telah dirumuskan. ${ }^{59}$

Dalam perencanaan dan pengelolaan lembaga pendidikan Islam untuk mencapai tujuan yang telah dirancang, seorang manajer harus memiliki kemampuan konseptual (conceptual skill), kemampuan teknis (tehnical skill), dan hubungan insani (human skill). Ketrampilan konseptual adalah kemampuan untuk memahami kompleksitas organisasi pendidikan secara utuh sesuai dengan prilaku dan kegiatan organisasi. Kegiatan tersebut harus sejalan dengan tujuan organisasi secara keseluruhan dan bukan hanya untuk kepentingan seseorang atau kelompok. Adapun kemampuan teknis merupakan

${ }^{56}$ Ibid: 150 .

${ }^{57}$ Sulistyorini, Manajemen Pendidikan Islam; Konsep, Strategi dan Aplikasi, Yogyakarta: Penerbit TERAS, 2009, hal. 33.

${ }^{58}$ Ibid.

${ }^{59}$ Sulistyorini, Manajemen Pendidikan Islam; Konsep, Strategi dan Aplikasi, Yogyakarta: Penerbit TERAS, 2009, hal. 34. 


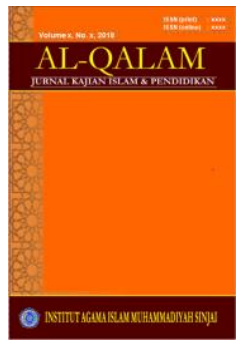

AL-QALAM

Jurnal Kajian Islam \& Pendidikan

Volume 06 No 022014

ISSN (print) : 1858-4152

ISSN (online) : -

Homepage : http://journal.iaimsinjai.ac.id/index.php/al-qalam

kemampuan dalam memberdayakan pengetahuan, metode, teknik, dan peralatan yang diperlukan dalam unjuk kerja tugas-tugas yang spesifik yang diperoleh melalui pengalaman, pelatihan, dan pendidikan. Sedangkan ketrampilan hubungan manusiawi merupakan kemampuan dan pertimbangan dalam melaksanakan kerjasama melalui orang lain, termasuk di dalamnya pemahamn tentang motivasi dan aplikasi kepemimpinan yang efektif. ${ }^{60}$

Dalam operasionalnya di lembaga pendidikan Islam (madrasah/sekolah), manajemen pendidikan Islam memiliki beberapa bidang garapan yang menjadi substansi manajemen pendidikan Islam. Yaitu: ${ }^{61}$

a. Manajemen kurikulum pendidikan Islam

b. Manajemen guru pendidikan Islam

c. Manajemen kelas pendidikan Islam

d. Manajemen kesiswaan pendidikan Islam

e. Manajemen sarana dan prasarana pendidikan Islam

f. Manajemen keuangan pendidikan Islam

g. Manajemen partisipasi masyarakat pendidikan Islam

h. Manajemen kepemiminan kepala sekolah pendidikan Islam

\section{KESIMPULAN}

Pada hakikatnya di setiap kehidupan kita terdapat unsur-unsur manajemen, jika sepenuhnya kita sadari terhadap beberapa fungsi sebagai seorang hamba Allah, untuk menemukan kebahagiaan, keselamatan dengan memfungsikan segala sesuatunya. Oleh karena itulah segala perencanaan, tindak tanduk perbuatan kita hendaklah disesuaikan dengan jalur dan garis yang telah diberikan pedoman, guna mencapai hasil yang diharapkan.

Al-qur'an menyebutkan bahwa manusia itu dijadikan terdiri dari sukusuku, kelompok-kelompok dan berbangsa-bangsa agar sesama mereka dapat saling mengenal, berhubungan, bekerjasama untuk berbagai kepentingan yang banyak dilakukan oleh masyarakat luas. Akan tetapi terhadap manusia yang berkelomok itu untuk dapat lebih mudah mencapai hasil tentu sangatlah diperlukan proses manajemen yang dijalankan dengan baik, seperti proses perencanaan, pengorganisasian, penggerakan, dan pengawasan untuk bisa mencapai tujuan. Apalagi dalam hal pendidikan sangat perlu adanya konsep manajemen yang baik dan sesuai dengan yang diatur dalam Al-qur'an.

\section{DAFTAR PUSTAKA}

${ }^{60}$ Ibid: 35 .

${ }^{61}$ Ibid: 36. 


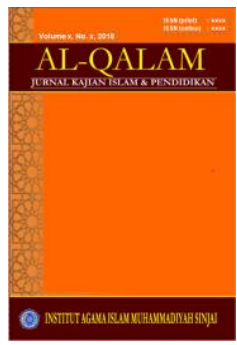

AL-QALAM

Jurnal Kajian Islam \& Pendidikan

Volume 06 No 022014

ISSN (print) : 1858-4152

ISSN (online) : -

Homepage : http://journal.iaimsinjai.ac.id/index.php/al-qalam

Acmadi, Ideologi Pendidikan Islam; Paradigma Humanisme Teosentris, Yogyakarta: Pustaka Pelajar, 2010.

Ali, Mohammad, Reinvensi Pendidikan Muhammadiyah, Jakarta: al-Wasat Publishing House, 2010.

Al Munawar, Said Agil Husain, Aktualisasi Nilai-nilai Qur'ani dalam Sistem Pendidikan Islam, Ciputat: PT. Ciputat Press, 2005.

Departemen Agama RI Direktorat Jenderal Kelembagaan Agama Islam Jakarta, Desain Pengembangan Madrasah, Jakarta: Departemen Agama RI Direktorat Jenderal Kelembagaan Agama Islam Jakarta, 2004.

Suharto, Toto, dkk, Rekonstruksi dan Modernisasi Lembaga Pendidikan Islam, Yogyakarta: Global Pustaka Utama Yogyakarta, 2005.

Sulistyorini, Manajemen Pendidikan Islam; Konsep, Strategi dan Aplikasi, Yogyakarta: Penerbit TERAS, 2009.

Surakhmad, Winarno, dkk, Reformasi Pendidikan Muhammadiyah Suatu Keniscayaan, Yogyakarta: Pustaka Suara Muhammadiyah, 2003.

Usman, Husaini, Manajemen; Teori, Praktek dan Riset Pendidikan, Jakarta: PT. Bumi Aksara, 2008. 